\title{
Human Resource Management: The Key to Public Management Reform
}

\author{
Rangson Prasertsri \\ Vice President for Research and Development, Chaopraya University, Thailand, \\ (Email:rangsonpss@ hotmail.com)
}

\begin{abstract}
With much of the world concerned about the problems of responding to the increasing demands of an ever more-informed citizenry, the field of Public Management runs the risk of becoming, if not completely irrelevant, at least non-responsive to the needs of developing societies. This article is an attempt to suggest areas that need to be considered by scholars of Public Management in the years ahead, while paying particular attention to Human Resource Management and Thailand as a point of reference.
\end{abstract}

Keywords: Public management reform, importance of human resources, organizational change

\section{Introduction}

By and large, the history of Public Management has seen different scholars advocating different paradigms believed to be appropriate for public management in a Western culture. One especially notable change has dealt with the importance of human resources. Originally, and until fairly recently, the human resource (HR) function (or personnel management function) was viewed as primarily a management role that fit potential employees into pre-determined positions. Ehrlich notes that " $(\mathrm{t})$ he increased importance placed on the effective management of employees in world-class companies, however, has re-defined that role."'11] This is even truer for the public sector and is the key to Public Management Reform.

\section{Change}

One thing about the future that almost everyone can agree on is that the rate of change is increasing at an astonishing rate and the world as we know it will be substantially different from what it is today. Ghillyer begins his book on management by stating that: "Organizations today operate in a world of constant change. Technology and society are changing more rapidly than ever before."[2] It has been asserted that: "The dramatic growth of the Internet in recent years probably represents the single most important environmental trend affecting organizations and their human resource practices."[3] It is important that universities that offer programs in human resource development, when teaching about human resource management activities, "...prepare managers for the future, not managers who would have succeeded in a past that no longer exists."'[4] This, along with research aimed at understanding how to best employ the advantages of governance to achieve sustainable development, are the major challenges facing the field of Public Administration today. Because of this, developing "best practices" for human resource managers lies at the heart of effective PM reform.

This paper stems from the belief that the most important resources of any organization are not its size (number of employees) or the number of people who are served by the particular Department or Ministry, nor modern machinery. As societies move from production of things to production of information in the digital age, computers replace tool and die shops, garment makers, and other manufacturing facilities. In the United States, manufacturing jobs "...represent only $12 \%$ $15 \%$ of all U.S. jobs" [5] and the U.S. Bureau of Labor Statistics predicted that the information and services industry will account for more than 90 percent of the workforce growth in the next 10 years.[6] That same transformation is also taking place in Thailand, Singapore, Taiwan, Hong Kong and South Korea.[7] In all cases, the most important resources needed to compete in the modern 
digital world are a combination of knowledge and bright, talented people with creative minds who understand that public organizations need to change to be competitive in the future. Developing human capital, much more than machines, is the road to the future.

\section{IT and Knowledge Management}

Much of what one learned in a Ph.D. program for Administration only 20-25 years ago is irrelevant today. It is estimated that the “...global knowledge base has multiplied such that ninety seven percent of the collective body of knowledge in the world today, are things we did not know fifty years ago."[8] Today, some businesses are using Knowledge Management $(\mathrm{KM})$ to "...turn best practice into normal practice.”[9]

Globalization is bringing about many changes, one of the most important is new knowledge/ technology. "The 'company man' of the 1950s has become the 'digital person' of the new millennium."[10] A survey by the Society for Human Resource Management found that ...the top resource trend identified was technology."[11] This trend is increasing at an ever-faster rate. "It has been estimated that there will be more technological change in the next 50 years than in the last 1,000 years." [12] Wees stresses that employees need to be encouraged to think outside the box, to find better ways to solve familiar problems. They need to "...think critically about the information" they receive and to talk "...to other people to see how they solve these kinds of problems."[13] New technology facilitates this process. It will be the job of PM scholars to transfer the knowledge gained from that new technology to their students who will be the administrators of tomorrow.

In Bangkok, Imtiaz reports that "Advances in information and communications technologies (ICTs)...are set to play an increasing role in both reducing and managing the growth still to come."'[14] It will provide an administrator in Bangkok with up-to-date data on provinces throughout the country. Much of this new technology is based on computers that produce better information collection in less time, but it also involves new ways of thinking and new ideas.
In the public sector, the government provides a vast range of programs, from medical services and education to police and fire protection. What "customers" (the public) expect is information (feedback) that is crucial for, as Promoth Sudjitporn, CEO of Asiasoft stresses, it is important to "understand the product from the customer's perspective."[15] Successful public managers of the future will need to make use of the knowledge that exists at all levels of the organization (and, also, outside of it) to create a smoothly functioning organization capable of meeting the needs of tomorrow.

In the public sphere, the need is even more pressing. "Knowledge must be treated as a public asset and made accessible to all because it is a powerful tool for eradicating poverty, misunderstanding, and suspicion.”[16] Here, the "...role of universities is crucial as they are at the very heart of the knowledge society. ... (E)ducation and research (must) be closely connected with the knowledge transfer process."[17] The Dean of the Carnegie Mellon University Heinz School has stressed the real IT revolution is: “...about people acquiring skills and knowledge turning those skills and knowledge into innovation and that innovation into economic growth and opportunity...not just for themselves, but a large segment of the societies that they came from.”[18]

\section{Human Resource Development}

Advances in information technology will prove to be of little value if an organization fails to adequately develop the potential of its human resources. This is the most important resource of all. "According to the Council on Competitiveness ...human resources are the key to global competitiveness."[19] Or, put another way, "HR technology has the potential to either increase or decrease an organization's worth."[20]

Jack Welch of General Electric noted that increased productivity comes from “...challenged, empowered, excited, rewarded teams of people. It comes from engaging every single mind in the organization, making everyone part of the action, and allowing everyone to have a voice - a role - in the success of the enterprise. Doing so raises 
productivity not incrementally but by multiples...’[21]

One of the major changes that will be seen in the future is the type of people that are in demand. For one thing, historically men filled most of the upper management positions in Thai organizations. But, according to the Grant Thornton International Business Report survey, today "...the percentage of Thai women in senior management is the highest in the world at $45 \%$, more than twice the global average."[22] Also, in the past, a company or government Department hired a person because he/she had a specific skill. That was OK for then. If your company made a pen or a typewriter, it used the same technology (with slight modifications) for fifty years. But, not many people use typewriters anymore. In the future, Organizations will have to "...look for people who have the right attitude, as technical skills can be learned through on-the-job training."[23] Kriengsak notes, when climbing up the corporate ladder: "The higher you climb, the less technical skill is required. But you will need to sharpen your people skills in order to influence others.'[24]

If government Departments hope to be relevant in the future, they must make sure that: 1) they hire people who want to learn new skills; 2) the organization must provide those people with sufficient free time to learn, and; 3) people must be provided the opportunity (training) to learn. People in charge of human resource development in government agencies will need to hire people who can teach themselves new skills, or, at the very least, people who can learn if they are provided with new training. They also will have to be more selective in the types of people they hire or promote to managerial positions. Just having an MBA or an MPA is no longer a sufficient qualification. Training is required to develop the "...qualities in human resources that will enable them to be more productive and thus to contribute more to organizational goal attainment"[25] Leaders “...must make sure that all employees have the appropriate resources, including technology as well as personal development opportunities...’[26]

\section{Employee Retention}

Being able to hire qualified, creative people is only the first step. Smith and Mazin note: "After you hire good people-you need to keep them working for your company and not the competition, and keep them content, motivated, and focused on the business."[27]

One other important change Asian government Departments and Ministries will see in political cultures as more and more people learn to compete in the global market is that individuals will no longer be tied to a particular job. This has a lot to do with the changing nature of work. Before, it was manufacturing, but twelve years ago, the Economist, citing a recent OECD study, reported that "...more than half of the total GDP the rich economies is now knowledgebased...(and) knowledge workers...from brain surgeons to journalists...[now] account for eight out of ten new jobs.’'[28]

Today, smart, ambitious people (who have the creative minds that will be required in tomorrow's digital world) are beginning to change jobs. In some cases it may be for more money, but money and/or job security may not be enough. Instead, Maslov's higher-level needs have moved to the fore. People leave stressful situations for a more relaxed atmosphere. Others change jobs to have more free time (to be with their families, or simply to play golf). They understand that THEY are in demand. New companies with new ways of thinking are offering new opportunities. Smart people will no longer be attached to the same company or government office for life; they will go where there is more opportunity, or a better work environment, or both.

In order to retain good workers, governments will have to create better work environments (better safety, more healthcare for employees, etc.) in the future. Smith and Mazin note that:

"Today's workers bring a lot more to their employers, but they also demand more in return. One of the expectations is to be given more flexibility to be able to achieve their own personal goals, whatever they may be. The pivotal elements in the 'offer package' of today focus on tailoring the job to the individual needs of the employees... It is the satisfaction of these lifestyle needs that make the difference today in successful hiring and 
management processes... The dissatisfied employee is highly mobile and can easily search elsewhere.”[29]

Globalization will lead first to changes in the private sector. "Increasingly, employers are finding that helping workers to create and maintain a balance between their home and work lives is the key to retaining the best employees."[30] These changes in ways of thinking then will spread out into society as a whole; and finally they will be adopted by the public sector.

Preecha Watcharapai, Secretary-General of the Civil Service Commission noted: "If we want talented workers, we have to compete with the private sector and not wait idly by for them to come to us." [31] People with creative minds can negotiate their salaries, for example, one million baht per year for three years. Preecha stated that "The pay is determined by supply and demand."[32] This is an acknowledgment that the environment has changed and that to be competitive in the future, bureaucracy must also change.

Human resource managers will need not only to be aware of these coming changes, but be ready and able to shape them in positive directions. Ulrich, Brockbank, Yeung, and Lake found that "...the importance of understanding and being competent in the practice of managing organizational change for HR practitioners" was the most important of the "critical competencies for HR practitioners to be effective in their jobs."[33]

According to Teerana Konglazae, the project manager of the Hewitt Best Employers in Thailand 2009 Study, “...executives should listen to employees and get along with staff at all levels, including labourers, to create a team spirit, and learn about real problems facing staff aside from reading only reports that may be misleading."'[34] Mary Parker Follett knew this years ago;[35] one does not need to reinvent the wheel; what is needed is more research based on such profound, but longignored insights.

At the beginning, it was stressed that the most important resources that an organization has to enable it to compete in tomorrow's world are its people and knowledge. But, until recently, the human resource potential was hardly ever tapped. Fifty years ago, Douglas McGregor rejected the Classical approach to administration. He believed that people enjoy intellectual challenges. They seek opportunities for responsibility and for selfinitiative. Most workers have the capacity to exercise a relatively high degree of imagination, ingenuity, and creativity in the solution of organizational problems, but the intellectual potential of the average worker in modern industrial life is only partially utilized.[36] For nearly half a century, the wisdom of people like McGregor was ignored. However, in the past $15-20$ years that has changed, and changed dramatically.

\section{Conclusion}

Public employees are comfortable with that to which they have become accustomed and thus tend to resist changes in either an organizational structure or the development of human resource practices. But the external environment has changed, and, to remain competitive, governmental organizations need to address the challenges of that new environment. "HR professionals who realize and embrace the new technology are the ones who will succeed.'[37] According to Wolfgang Lux: "Most Asian companies...(have) not adopted the type of global thinking needed for a fast changing business world."[38] This is even truer for the public sector. PM scholars can help to facilitate the evolution of management theory so that new public servants will be in a position to assist in the modernization of their Ministry or Department.[39] If schools of administration are going to continue to be a leading force in helping countries achieve sustainable development, they need to teach the future administrators to understand the needs of tomorrow so they can successfully help guide their home countries into that world. To remain relevant to scholars in most of the world, the field of Public Management must help them address this need. This, above all else, is the key to successful Public Management reform.

\section{References}

[1]Clifford J. Ehrlich, "Human Resource Management: A Changing Script for a Changing World", Human Resource 
Management, Spring 1997, Vol. 36, No. 1, p. 86.

[2]Andrew W. Ghillyer, Management Now, (New York: McGraw-Hill, 2012), p. 4

[3]Ibid., p. 5.

[4]Randy L. DeSimone, Jon M. Warner, and David M. Harris, Human Resource Management (Fort Worth, TX and others: Harcourt, Inc., 2002), p. 527.

[5]Robert L. Mathis and John H. Jackson, Human Resource Management (Australia and others:: Thompson, South-Western Press, 2004), p. 35.

[6]Dave Patel, "Managing Talent", HRMagazine 47 (March 2002), p. 112.

[7]In 2006, the percentage of Thailand's GDP attributable to services passed that of industry for the first time. Services constituted about 45.2 percent of GDP, followed closely by industry with a 44.9 percent share. See: http://lcweb2.loc.gov/frd/cs/profiles/Thaila nd.pdf By 2011, that gap grew to nearly 10 percentage points.

[8] Eugene Aucoin, "Public Sector Reform and the Changing Nature of Public Employment: Motivation and Leadership", paper presented to the panel on Public Administration Between Globalisation and Decentralisation: Implications for Education and Training at the Conference of the International Association of Schools and Institutes of Administration, Istanbul, Turkey, 17-20 June 2002, p. 4.

[9]PriceWaterhouseCoopers, "Turning best practice into normal practice", Bangkok Post, 5 August 2008, p. B3.

[10] Shawn Smith and Rebecca Mazin, The H $\mathrm{R}$ Answer Book (N.Y. and others: American Management Association, 2004), p. ix.

[11] "What's Ahead for HR? SHRM Research Identifies Top Trends:l”, H R Focus, Vol 79 (September 2002), p. 8, as cited in R. Wayne Mondy and Robert M. Noe, Human Resource Management (Upper Saddle River, N.J.: Pearson Prentice Hall, 2005), p. 10.

[12] Tony Waltham, "Human capital the real IT revolution: Power lies in people, not technology", Bangkok Post, 20 August 2008, D3.

[13] R. Wayne Mondy, Robert M. Noe, Shane Premeaux, Human Resource Management (London: Prentice-Hall, 1999), p. 240.
[14] Julie Britt, "Focused HR Technology Can Add Value", in HRMagazine Vol. 47 (March 2002), p. 24, as cited in R. Wayne Mondy and Robert M. Noe, Human Resource Management (Upper Saddle River, N.J.: Pearson Prentice Hall, 2005), p. 10.

[15] Jack Welch, "A Look at Productivity", The Wall Street Journal, June 21, 1994, p. A22.

[16] Sanitsuda Ekachai, "Questions for the PM-elect”, Bangkok Post, 7 July 2011, p. 11.

[17] Umesh Pandey, "Companies must 'have a dream"”, Bangkok Post, July 10, 2007, p. B3.

[18]Kriengsak Niratpattanasai, "Coaching Myths for the Busy Leader", Bangkok Post, 11 July 2011, p. B3.1 Shawn Smith and Rebecca Mazin, The H R Answer Book (N.Y. and others: American Management Association, 2004), p. $\mathrm{x}$.

[19] Ibid. p. 87.

[20] Achara Deboonme and Chulart Saengpassa: "Civil service changes tack, head-hunts for graduates" The Nation, 23 July 2007, p. 1B.

[21] Ibid.

[22] D. Ulrich, W. Brockbank, A.K. Yeung, and D.G. Lake, "Human Resource Competencies: An Empirical Assessment", Human Resource Management, Vol. 34, pp. 473-495, as cited in: W. Warner Burke, "What Human Resource Practitioners Need to Know for the Twenty-First Century", Human Resource Management (Spring 1997), Vol. 36, No. 1, p. 72.

[23] Bill Leonard, "Straight Talk", HRMagazine, Vo. 47 (Jan. 2002), pp. 4651.

[24] Sriwipa Siripunyawit, "MBA no substitute for people skills", Bangkok Post, July 16, 2005, p. B2.

[25]Promising steps are already being made in this direction. See, for example: Jiracha Vicheanpanya Onjaree Natakuatoong, Ph.D. and Vicharn Panich, M.D., M.S., "Development of Efficient Knowledge Management Composite Indicators" in: http://www.waseda.jp/assoccioacademy/pdf/vicheanpanya.pdf

[26 ] Achara Deboonme and Chulart Saengpassa. Civil service changes tack, head-hunts for graduates. The Nation, 23 July 2007, p. 1B. 
[27 ] Aucoin, Eugene. "Public Sector Reform and the Changing Nature of Public Employment: Motivation and Leadership", paper presented to the panel on Public Administration Between Globalisation and Decentralisation: Implications for Education and Training at the Conference of the International Association of Schools and Institutes of Administration, Istanbul, Turkey, 17-20 June 2002.

[28 ] Julie Britt, "Focused HR Technology Can Add Value", in HRMagazine Vol. 47 (March 2002), p. 24.

[ 29] Burke, W. Warner. "What Human Resource Practitioners Need to Know for the Twenty-First Century", Human Resource Management (Spring 1997), Vol. 36, No. 1, p. 72.

[30 ] Certo, Samuel C. Modern Management, (Upper Saddle River, N.J.: Prentice Hall, 2003).

[31 ] Chadamas Chinmaneevong, "Employers urged to do more to help talented staff add value", Bangkok Post, 5 August 2008, p. B10.

[32 ] Dess, Gregory G. and Joseph C. Picken, "Changing Roles: Leadership in the 21st Century", Organizational Dynamics (Winter 2000), p. 18.

[33 ] DeSimone, Randy L., Jon M. Warner, and David M. Harris, Human Resource Management (Fort Worth, TX and others: Harcourt, Inc., 2002).

[34 ] Ehrlich, Clifford J. "Human Resource Management: A Changing Script for a Changing World", Human Resource Management, Spring 1997, Vol. 36, No. 1 ,

[35] Follett, Mary Parker. See : http://www.follettfoundation.org/mpf.ht $\mathrm{m}$

[36 ] Ghillyer, Andrew W. Management Now, (New York: McGraw-Hill, 2012

[37 ] Heskett, James L. and Leonard A. Schlesinger, "Leading the HighCapability Organization: Challenges for the Twenty-First Century", Human Resource Management (Spring 1997), Vo. 36, No. 1, p. 112.

[38 ] Ioan Voicu, "Towards Innovative Societies: Advancing the objective of innovation is expected to help bridge the digital, scientific, and development divide between rich and poor countries",
Bangkok Post, August 12, 2007, Sec. 1, p. 10.

[ 39] Jiracha Vicheanpanya Onjaree Natakuatoong, Ph.D. and Vicharn Panich, M.D., M.S. "Development of Efficient Knowledge

[40 ] Management Composite Indicators" in: http://www.waseda.jp/assoccioacademy/pdf/vicheanpanya.pdf

[41 ] Knowdell, Richard L. "The 10 New Rules for Strategizing Your Career:, The Futurist, Vol. 32 (June 1998), p. 1

[42 ] Kriengsak Niratpattanasai, "Coaching Myths for the Busy Leader", Bangkok Post, 11 July 2011, p. B3.

[ 43] Leonard, Bill. "Straight Talk", HRMagazine, Vo. 47 (Jan. 2002), pp. 46-51.Mathis, Robert L. and John H. Jackson, Human Resource Management (Australia and others:: Thompson, South-Western Press, 2004),

[ 44] McGregor, Douglas. The Human Side of Enterprise (New York: McGraw-Hill, 1960).

[45 ] Mondy, R. Wayne and Robert M. Noe, Human Resource Management (Upper Saddle River, N.J.: Pearson Prentice Hall, 2005).

[ 46] Mondy, R. Wayne, Robert M. Noe, Shane Premeaux, Human Resource Management (London: Prentice-Hall, 1999).

[ 47] Mugbil, Imtiaz., "Technology changing travel for the better", Bangkok Post, 11 August 2008, p. B10.

[48 ] Patel, Dave. "Managing Talent", HRMagazine 47 (March 2002), p. 112.

[ 49] PriceWaterhouseCoopers, "Turning best practice into normal practice", Bangkok Post, 5 August 2008, p. B3.

[50] Sa nitsuda Ekachai, "Questions for the PM-elect”, Bangkok Post, 7 July 2011, p. 11.

[51 ] Shareinvistor, "How Asiasoft stays on top of its game", Bangkok Post, 25 July 2008, p. B4.

[52 ] Smith, Shawn and Rebecca Mazin, The H R Answer Book (N.Y. and others: American Management Association, 2004).

[ 53] Sriwipa Siripunyawit, "MBA no substitute for people skills", Bangkok Post, July 16, 2005, p. B2.

[ 54] Ulrich, D., W. Brockbank, A.K. Yeung, and D.G. Lake. "Human Resource 
Competencies: An Empirical Assessment", Human Resource

Management, Vol. 34, pp. 473-495.

[ 55] Umesh Pandey, "Companies must 'have a dream"”, Bangkok Post, July 10, 2007, p. B3.

[ 56] Waltham, Tony. "Human capital the real IT revolution: Power lies in people, not technology", Bangkok Post, 20 August 2008, D3.

[ 57] Wees, David. "Thinking Outside the Box”, Bangkok Post, 8 July 2008, p. E3.

Welch, Jack. "A Look at Productivity", The Wall Street Journal, June 21, 1994, p. A22. 